\title{
A National Council of OCEANOGRAPHY GRADUATE STUDENTS
}

\author{
By Matt Ellis, Mike Cook, Martin Ebel and Ann Jochens
}

\begin{abstract}
Almost two years ago, in the first issue of Oceanography. a proposal was made to form a national Council of Oceanography Graduate Students (COGS), comprised of representatives from member institutions and governed by an elected executive committee. Since that time, little has been done to advance this idea. Now, the Oceanography Graduate Council (OGC) at Texas A\&M University would again like to set this concept into motion.

Many people have responded to the initial proposal with. "Yes, it's a good idea, but what purpose will it serve?" A national organization representing oceanography graduate students offers many interesting and useful possibilities. One important question facing graduate students is funding during their careers in school. How do the tuition, pay and tuition waiver vary from school to school? COGS could be used to gather this information and send it to inquiring students. Upon graduation, what jobs are available? Coming straight out of school, we are sometimes unaware of the total realm of job possibilities. COGS could collate information about universities, research institutions and commercial firms that are eager to find scientists. Similar in-
\end{abstract}

Matt Ellis, Mike Cook, Martin Ebel, Texas A\&M University, Dept. of Oceanography: Ann Jochens. World Ocean Circulation Experiment, TAMU, Dept. of Oceanography. College Station.. TX 77843. formation could be distributed regarding post-doc positions.

When students attend meetings, with or without their professors, they tend to meet only those people with whom the professor associates. At meetings, professors may have limited free time, leaving students with little more than sightseeing opportunities. COGS could provide students the chance to meet other students at national and regional meetings. We are all to be colleagues, and the earlier we can meet. the greater cohesiveness our scientific community will have. An opportunity to meet as students from various institutions will encourage diverse and multidisciplinary research opportunities after graduation.

The Oceanography Society (TOS) is openly urging students to participate, as shown by the Studentia page featured regularly in this magazine. As of yet, we have done little to take advantage of this generous opportunity to advance student interests nationally. COGS could make use of this page to advance student concerns. There has been some movement within TOS for student representation, but this privilege must be earned first. If we actively demonstrate that we are interested in what happens within our professional community as students, then we could rightfully petition for student representation on the executive council of TOS.

We can become an organized group to promote local student oceanography or- ganizations, provide a forum for development of student views, and promote student interest and awareness in the professional world of oceanographers. Let us join together and unite the oceanography student groups at universities and institutions worldwide. As we start the 1990s, let us form a cohesive organization that will be firmly in place to meet the challenges of the $21 \mathrm{st}$ century.

In order to facilitate the organization of COGS, the OGC at Texas A\&M University is willing to coordinate matters until we have a full council in place. We will attempt to do this in two manners. First, to promote an exchange of ideas and provide information to students, a Telemail bulletin board named GRAD.STUDENTS has been established by Omnet, Inc., for our benefit. The bulletin board provides a convenient way to discuss matters of student concern. Suggestions and ideas about COGS are especially welcomed. Second, letters will be sent to oceanography programs to solicit help and local leadership. We suggest, as a worthy first project, that COGS organize a student symposium as part of the next major TOS meeting, which will be held in the spring of 1991. Formore information, please contact Matt Ellis at Texas A\&M University, Department of Oceanography, College Station. TX 77843, telephone (409) $845-8178$, or leave a message on the student bulletin board. $\square$ 